\title{
INFOTAINMENT IN THE CAMPAIGN FOR THE 2015 SPANISH GENERAL ELECTION: AN ANALYSIS OF EL HORMIGUERO FROM A GENDER PERSPECTIVE
}

\author{
María Pilar Rodríguez \\ maria.pilar@deusto.es \\ Universidad de Deusto
}

\author{
Miren Berasategi \\ miren.berasategi@deusto.es \\ Universidad de Deusto
}

Recibido: 22-02-2016

Aceptado: 28-05-2016

\section{Resumen}

En el nuevo panorama de comunicación política caracterizado por el infoentretenimiento en los programas televisivos de mayor audiencia, este artículo analiza la aparición de cuatro representantes en el programa El Hormiguero durante el período de la campaña electoral con la intención de explorar la presencia de motivos sexistas o tradicionalmente asociados a los estereotipos de género. Las conclusiones advierten una disminución evidente de los estereotipos tradicionalmente asociados al género en el tratamiento mediático. El análisis revela una casi total eliminación de estereotipos sexistas en las entrevistas; sin embargo, el tono sexista permanece en los espacios del programa ligados al humor y al entretenimiento.

Palabras Clave: Mujeres políticas, elecciones generales, infoentretenimiento, estereotipos sexistas.

\begin{abstract}
Within the new landscape of political communications characterized by infotainment in prime time television programs, this article analyzes the presence of four political representatives in $E l$ Hormiguero TV program in order to explore if their appearances reinforce gender stereotypes. The analysis of the television programs reveals a substantial progress in the elimination of gender stereotypes that the media traditionally conveys and reproduces in political campaigns. The analysis reveals a practical elimination of gendered bias in the interviews; the sexist tone remains, however, in other spaces of the television program linked to humor and entertainment practices.
\end{abstract}

Keywords: Women politicians, general elections, infotainment, sexist stereotypes. 


\section{Introduction}

The last decades have witnessed the progressive arrival of women to the public scene and to politics in particular. Despite the undeniable increase in the quantitative presence of women in party lists, and the concern of political parties to include a significantly higher number of women in their structures, the spaces of power in politics and the media are still overwhelmingly occupied by men. For useful information on how the media portray men and women in spaces of power like politics and finance, we recommend the Spanish edition of the Global Media Monitoring Project 2015 (GMMP). In this report, for 2015, only 28\% of the subjects and sources in print, $\mathrm{TV}$, and radio news were women, a percentage which increases to $33 \%$ when analyzing digital newspapers and Twitter. As subjects of the news, women are consistently below $30 \%$ of the total: $28 \%$ across newspapers, $26 \%$ on radio, and $29 \%$ on television. In a thematic categorization, women are in the minority in all theme areas except for the one dealing with Crime and Violence, where they are present in $51 \%$ of the news items. When discussing traditionally male areas, the presence of women only amounts to $31 \%$ in Politics and Government and to $20 \%$ in Economy. Looking at the presence of women as sources, they predominantly appear providing popular opinion $(43 \%)$, speaking from their personal experience (37\%), and as subjects of the news (35\%). Their lowest percentage of contribution to the news is as experts, with 9\% (Simelio, 2015: 5). The GMMP concludes that women are still marginalized in the media, and are usually depicted at home or at social environments, identified by their family relations, and heavily underrepresented as professionals or experts. The voice of authority still belongs to men wielding public power from a position in the hierarchy.

The treatment afforded by the media to women politicians has been the subject of extensive study, particularly in USA electoral campaigns. Kathleen Dolan explains that women candidates are often viewed through the lens of gender stereotypes and, in many cases, the public debate is rooted "in reactions to their sex and in gender stereotypes about the appropriate role for women in public life" (Dolan, 2015: 2). The media consistently associate women politicians to family-related environments, to homemaking, and to physical appearance, which constitutes a filter through which they are perceived as political figures. James Devitt (1999) states that reporters tend to focus more on their personal life and family and less on political issues when covering women candidates. The tendency to construct the subjectivity and perception of women politicians according to the values of female stereotypes (weakness, homemaking, clothing and make-up, care and affection) and in contrast with those of male stereotypes (reliability, authority, power, confidence) often complicates depicting women as leaders (Rodríguez, 2012: 178). The influence of the media in our social perception of women, and ultimately in the collective imagination, hinders the access and advance of many women to 
positions of political leadership. Jennifer L. Lawless and Richard L. Fox find that women are substantially less likely than men to demonstrate their ambition to seek elective office; women are less likely than men to be recruited to run for office; and are less likely than men to think they are qualified to run for office (Lawless and Fox, 2012: 124-126). This gender gap in political ambition persists across generations and over time. Despite cultural evolution and society's changing attitudes toward women in politics, running for public office remains a much less attractive and feasible endeavor for women than men (Lawless and Fox, 2012: 167).

This situation leads to the persistence of the glass ceiling in politics. As Nancy Lockwood informs, the term was coined in a 1986 Wall Street Journal report on corporate women by Carol Hymowitz and Timothy D. Schellhardt. The glass ceiling is a concept that most frequently refers to barriers faced by women who attempt, or aspire, to attain senior positions (as well as higher salary levels) in corporations, government, education, and nonprofit organizations (Lockwood, 2004: 2). Pamela O'Leary and Shauna Shames (2015) point to a gender gap in political ambition as the most significant barrier to increasing the number of women in office. When equally qualified women and men are surveyed, women are much more unlikely to report wanting to run for office. Additionally, as Kathleen Dolan reports, "women devalue their own skills and abilities more than do men and are much less likely to see themselves as viable candidates than men" (Dolan, 2015: 7).

The connection between the persistence of the glass ceiling and the lack of political ambition by female candidates deserves a further comment. The particular case of Hillary Clinton in the 2008 primary elections is chosen here as a particularly relevant case to emphasize how media treatment may be a significant factor in the reluctance of female candidates to aspire to positions of power and, therefore, to perpetuate the existence of the glass ceiling. Hannah Groch-Begley (2016) has elaborated a report that compiles the accusations that Clinton received at the time; among others, the following are worth mentioning. She is attacked for being in such position due to her husband's merits and not her own; she is censured for being too tough and too "male" and, at the same time, for being soft and feminine; references are made to her appearance, figure, height, weight, tone of voice, hair, cleavage and emotional instability. She is even accused of pimping her own daughter with the delegates to ensure her votes. After reading the report, the tremendous exposure to the private life of the candidate in the media is revealed as a powerful deterrent to the advancement of positions of power.

We will return to these notions in our analysis of the results of this study in order to provide some considerations regarding the present and future of women politicians and how they are depicted in the media. In this article, TV content is analyzed according to the principles of discourse analysis applied to television. To this end, we have selected the TV program El Hormiguero for the reasons that will be detailed in section 3. Methodology, which will also explain the methodology applied to the analysis and provide the justification for this choice. 


\subsection{Objectives}

The purpose of the present paper is to analyze the presence of the principal candidates to the Spanish general election of December 20, 2015, in the television program El Hormiguero, broadcast by Antena 3 on October 6 (with Soraya Sáenz de Santamaría, from the Popular Party, as guest), November 3 (with Pablo Iglesias, from Podemos), November 24 (with Albert Rivera, from Ciudadanos), and December 8 (with Pedro Sánchez, from PSOE, the Spanish Socialist Party) to study if the traditional stereotypes associated to the treatment of male and female politicians during political campaigns are maintained in the television program selected. For our purposes we have performed a thematic analysis of the content of discourse along three categories which are closely related to the reproduction of stereotypes and of sexist discourses and behaviors. Such categories are the ones which consistently appear in literature (Devit, 1999; Lenz and Chappel, 2011; Rodríguez, 2012; Hayes, Lawless, and Baitinger, 2014) when analyzing the treatment of female and male candidates in political elections: private life, physical appearance, and sexist stereotypes.

\subsection{Methodology}

The reason for choosing television over other media is the conclusion provided by the Spanish General Media Survey (EGM), and commented upon by the Global Media Monitoring Project 2015, that in the year 2014 television was the medium with the highest impact, with a consumption rate of $88.6 \%$ of the total population. After television came the Internet $(69.3 \%)$, radio (61\%), magazines (41\%), and newspapers with 29.8\% (Simelio, 2015: 6). The TV program El Hormiguero is the talk show with the highest audience ratings in its time slot, and had representatives of the four main political parties as guests during the campaign. It is broadcast by Antena 3 from Monday to Thursday at 21:45, although the programs with the three male representatives were broadcast on Tuesdays at 22:30, in an effort by the channel to keep the audience of Champions League soccer games tuned in (as those were broadcast just before the talk show). Their audience ratings were as follows: October 6 (Sáenz de Santamaría): $3,125,000$ viewers (16.5\% share); November 3 (Iglesias): 3,823,000 viewers $(21.7 \%)$; November 24 (Rivera): 3,026,000 viewers (17.1\%), and December 8 (Sánchez): 2,836,000 viewers (15.6\%). All four programs were over the average rating, which in the 2014-2015 season was 2,594,000 viewers and $13.5 \%$ share.

For the analysis of the shows selected we have used the model developed by Teun A. van Dijk for critical discourse analysis (CDA), specifically applied to audiovisual and content analysis: "a type of discourse analytical research that primarily studies the way social power abuse, dominance and inequality are enacted, reproduced, and resisted by text and talk in the social and political context" (Van Dijk, 1999: 23). CDA reveals that the use of language (in 
discourse and in communication in general) also has cognitive, emotional, social, political, cultural, and historical dimensions. From this point of view, it becomes relevant to examine the tensions that Spanish politics and society experience around the topic of how women are treated and valued, and how men and women are differently portrayed by television. Speaking in broad terms, audiences tend to accept the knowledge and opinion conveyed by the media they trust, particularly if these go unchallenged by dissenting discourses or by other sources of information. As Van Dijk states, those in power have preferential access to the public discourse, which they are able to control. Therefore, many people will not only interpret the world in the way that the powerful present it, but will also act according to the interests of the elite (Van Dijk, 1999: 32). For our purposes we have performed a thematic analysis of the content of discourse along the three categories mentioned in the previous section (private life, physical appearance, and sexist stereotypes) which are closely related to the reproduction of stereotypes and of sexist discourses and behaviors, as the following section explains.

These three categories are selected upon observation of the results of previous investigations carried out by the authors. In a detailed analysis of representation of male and female candidates in the Spanish press, the scrutiny of headlines, news, visual images and opinion articles revealed a notorious discrepancy between the attention paid to the private lives and the physical appearance of female and male candidates. Whereas female political representatives were constantly exposed in relation to their roles as wives and mothers, this was never the case with their male counterparts. Sexist discourse was particularly present in the opinion section of the newspapers, and humor was a tool implemented to hide sexist and discriminatory practices. In the literature on the treatment of media representation of female candidates such themes are recurrent; therefore, the analysis of the television programs around such issues is particularly relevant.

\section{Analysis}

The first point that we must address in this section is the very fact that these four political figures appeared in a nighttime talk show, where they had to show their abilities as entertainers in addition to being interviewed by the director and host of the show, Pablo Motos. Specifically, and in chronological order, Sáenz de Santamaría displayed her dancing abilities, Iglesias sang, Albert Rivera took part in a car race, and Sánchez played billiards. Such display of skill was unheard of in previous political campaigns and can be considered a manifestation of the infotainment 1 phenomenon.

\footnotetext{
${ }^{1}$ Without italics, as it is already a widely accepted term in communication studies.
} 
Although this is not the place to elaborate on the origins and development of the concept of infotainment, the term is a portmanteau of information and entertainment, as described by Daya Thussu:

"[...] as television news has been commercialized, the need to make it entertaining has become a crucial priority for broadcasters, as they are forced to borrow and adapt characteristics from entertainment genres and modes of conversation that privilege an informal communicative style, with its emphasis on personalities, style, storytelling skills and spectacles" (Thusu, 2007: 3).

From a philosophical standpoint, several authors have made a direct connection between societies with a capitalist mode of production and the dominance of spectacle. Each from their own perspective, Guy Debord (1995), Jean Baudrillard (1994), and Gilles Lipovetsky (2005) have criticized the role of the media in creating and appropriating a concept of reality which agrees with political and financial interests. Most critics of the extremely complex world of infotainment follow this line of thought and denounce its tendency to mix real and fictitious facts, to distort truth, and to privilege entertainment over engaging the audience's critical abilities. Conversely, some have highlighted its ability to entertain and expand the scope of democracy by incorporating a wide range of perspectives. Even Thussu, who is mostly critical of this phenomenon, admits: "In the new global infotainment sphere, multiple messages, voices and images can be transmitted instantaneously, from the many-to-the-many as well as one-toone, informing and entertaining, with identifiable social and political effects" (Thusu, 2007: 161). In any case, what seems to be a fact is that infotainment brings along an increase in audience ratings, as is the case of the program under study.

A relevant aspect concerns the audiences and the capacity of such television programs to act in an informative and even educational manner, since televised political debates during election campaigns represent significant moments for both the participants and the audience. As Stephen Coleman notes, an election is a most important moment in democratic societies for the politicians to show their superiority in open debate and for the voters to educate themselves about their voting choices. Coleman formulates four reasons for watching such debates as a contribution to the democratic process:

Firstly, televised debates are the best way of reaching a large audience of voters. Most voters obtain their political information from television more than any other source [...]. Secondly, there is an impressive body of data to indicate that televised debates have an educational impact [...]. Thirdly, televised debates help to equalise access to the mass media; the leader whose party is way behind in the polls has as much chance to win over the viewers as the leader whose poll lead suggests that he or she is already the virtual winner [...]. Fourthly, 
televised debates allow the public to come as close as they can to auditioning the candidates for national leadership (Coleman, 2000: 10).

The programs analyzed here cannot be strictly defined as political debates; nevertheless, the four candidates devoted a large portion of their speeches and responses to expose and explain their electoral programs and to convince the audiences that their party would be the most convenient for the future of the country. In such context, although many studies have dealt with the stylistic features of entertainment and their integration in the sphere of "serious" news and debates, and after a review of the existing literature Berrocal, Redondo, Martín, and Campos pointed out that infotainment manifests itself along three parallel but distinct lines of television content:

"Firstly, as light or minor news items (soft news) in traditional news programs. Secondly, as a tendency to discuss serious events in programs whose main purpose is to entertain. Finally, as parodies of current news programs" (Berrocal, Redondo, Martín, and Campos, 2014: 89).

The program that we have analyzed in the present paper clearly belongs to the second of these categories, since El Hormiguero is an entertainment program that frequently interviews national and international singers and actors. The appearance of political figures in this and other similar programs ${ }^{2}$ is a recent event, with the line separating political debate from entertainment programs having been clear until this campaign. The website of Antena 3 itself says so when discussing the presence of politicians in entertainment shows: "An increasing number of politicians, from all political parties, gather the courage to come to the set where $E l$ Hormiguero is recorded", only to add: "It used to be impossible to see such television moments, which politicians now provide with no ifs or buts. Maybe this is due to their being on air live and in prime time ${ }^{3 \%}$. Furthermore, several news items have linked audience ratings with the results of the election. Thus, Eduardo Fernández (2015) writes in the newspaper El Mundo an article under the headline "Albert Rivera cannot beat Pablo Iglesias in the 'elecciones' of El Hormiguero". This is the media context in which the four interviews have taken place.

In this group of four guest politicians, Sáenz de Santamaría represents a double anomaly: in the first place she is a woman, and secondly she is merely the reserve candidate to the presidency of the government. For both reasons her situation is different to that of the other three, male candidates. Similarly to the debate broadcast by Antena 3 on December 7, the three male guests are the heads of their respective political groups, whereas Sáenz de Santamaría is

\footnotetext{
${ }^{2}$ The main political representatives have been featured in several TV programs in the months leading to the campaign. Among others: En la tuya o en la mía (TVE1), Planeta Calleja (Cuatro), Al rincón de pensar (Antena 3), iQué tiempo tan feliz! (Telecinco), and Salvados (La Sexta).

3 "Los políticos en 'El Hormiguero': algo más que una entrevista" (Politicians in El Hormiguero: more than an interview) [on line] Available at: http://www.antena3.com/noticias/espana/politicos-hormigueroalgo-mas-que-entrevista_2015100700375.html [27/12/2015].
} 
the vice president of the Spanish Government and is acting as a stand-in for the head of the Popular Party, President Mariano Rajoy. As a matter of fact, rumors did spread about a socalled "Operación Menina" (operation lady-in-waiting), using the name of the famous painting by Diego Velázquez to refer to the possibility of Sáenz de Santamaría taking the place of Rajoy in a permanent manner. This is only another example of the generalized tendency to assign nicknames linked to physical appearance, height, and other features to women politicians. In any case, the relevant point here is to determine whether the appearance of these four politicians in El Hormiguero confirms or refutes the reproduction of stereotypes and sexist monikers as regards women politicians.

When looking into the four shows mentioned above, our content analysis will explore whether the four guests, through their answers, reflect any sexist ideology or behavior. To this end, as stated in previous sections, we have established three categories for the questions, answers, and behaviors: private life, physical appearance, and sexist stereotypes.

\subsection{Mentions of private life}

One of the main features of infotainment is its tendency to personalize: this is, as stated by Berrocal, Redondo, Martín, and Campos, something unavoidable in television, which as a medium requires ideas to have a face and voice. However, this trend is particularly noticeable in infotainment, where individual narratives are more important than complex realities. They point out that this is often seen in electoral campaigns as an efficient way to simplify politics (Berrocal, Redondo, Martín, and Campos, 2014: 92). In El Hormiguero the traditional trend is inverted, and Pablo Motos asks more questions about private life of their male guests than of Sáenz de Santamaría. In the case of Pablo Iglesias, Motos asks directly about his partner, to which he responds: "I am committed to my country, Pablo". The conductor insists: "The country would like to know whether you are committed to anyone in particular, someone who is able to soothe you. Otherwise you might come across as tense"; Iglesias is not daunted by his insistence: "I am committed to my country and extremely relaxed". Motos does not back down and asks for the third time: "Who do you watch TV with?", and Iglesias finishes the line of questioning with a terse: "Next question". For his part, Albert Rivera volunteered that the king and queen asked him about his partner, and cites among the drawbacks of political campaigning that privacy becomes inevitably compromised. After the conductor mentioned Rivera's daughter, Daniela, and inquired about her age, the leader of Ciudadanos spoke openly about her and even acknowledged: "I love her immensely". In the interview to Pedro Sánchez, he willingly mentioned his wife several times (and commented that he had had a great time watching the debate of the previous night in her company), and answered questions about his daughters (about their religious beliefs as well as the movies and music they enjoy). He was asked if he had ever forgotten his wife's birthday (he said he never had), and even when was the 
last time he got tipsy and if that got him in trouble with the wife. To all these personal questions the candidate answered openly and gladly.

The interview with Sáenz de Santamaría was particularly interesting, since Motos alluded to power over and over again to characterize her: he defined her as one of the most powerful women in Europe, and insisted: "You truly have a lot power. We had never had such a powerful guest in our program". This mention of "power" is very significant; as Manuel Castells asserts, power is a key aspect in social practices, values and institutions "and what is valued and institutionalized is defined by power relationships" (Castells, 2009: 11). It is, therefore, relevant to mention that Motos alludes to this notion as the first marker of his characterization of Sáenz de Santamaría. The conductor later mentioned the possibility of her becoming president, which she dismissed, although she asserted the importance of women's leadership and contributions ("the way we women have of seeing and communicating things"). It was however the vice president herself who mentioned her family and private life. She admitted that when criticism has been directed toward her personal life and her family it has been more hurtful than when attacks were aimed at her political actions. She mentioned her son, and the fact that he wakes up at seven thirty every morning, and, after kissing the bald head of one of the contributors of the show (mimicking something that Pablo Motos does at the beginning of every program), she stated: "Now I have some explanations to give at home".

In light of the above, we may conclude that there is no discriminatory treatment on the side of the show's host regarding his questions and comments about the private life of his guests. In any case, he performs an inversion of common practice by leaning towards professional aspects and the experience of power when his guest is a woman, taking the conversation far from intimate and family-related aspects. Whereas male candidates are either reluctant (Iglesias) or willing (Rivera and Sánchez) to share some aspects when prompted by the interviewer's questions, Sáenz de Santamaría volunteers information about her private life, reminding the audience about her role as a wife and mother, without being prompted by Pablo Motos. From this analysis we may derive some conclusions: first, advances have been made by inverting the practice of asking sexist questions from guests of the show. Secondly, we must commend the ability of the male interviewees to answer with spontaneity questions about their private life, contradicting common knowledge about the desire of male candidates to only communicate the core elements of their platform in television and refusing to comment on the most private and intimate aspects of their life. Lastly, comments by Sáenz de Santamaría reveal her wish to link her role as a wife and mother to her political work, reflecting in a fashion the lack of ambition mentioned by Dolan (2015) (evident in how fast she dismisses the possibility of her becoming the president of the government, and in her non-verbal communication and signs of disbelief) when the conductor mentions her as a powerful woman. However, we must pay close attention to her answer when prompted: "Do you feel that people are scared when they speak with you?" To this, she replied: "Not really. I wish, but not everybody fears me". This reflects her wish to be respected, which is something that not always happens. Despite her not providing further 
justifications or elaborations on her answer, we may read in her comment a longing for recognition of her political figure which has maybe never arrived, on occasion because of her gender. Nevertheless, Sáenz de Santamaría has repeatedly stated, in this show and in other appearances, that she is only a team member, one more piece in the machinery of her party, a common assertion in politics that may betray a denial of her own central role as a politician.

In the years in which Sáenz de Santamaría has displayed her activity in the political arena, she has always been framed as a tough, experienced, decisive, and knowledgeable leader who understood the problems and challenges facing the country. The characterization by Motos refers to such qualities; her allusions to her private life may be better understood in light of the description offered by Elizabeth Camille and Kasie Roberson, who claim that female candidates must strike a balance to prove themselves to be decisive, strong leaders while maintaining an adequate amount of femininity, and add: "at the same time that they are developing an image of independence and toughness, female candidates must be wary of violating gender norms" (Camille and Roberson, 2010: 76). In such light, the Vice President's reluctance to show a firm assumption of her real power and her immediate rejection of any political aspirations at the personal level may be interpreted within the social sphere of expectations of a female candidate that may damage her if she portrays a character which may be interpreted as too ambitious.

\subsection{Mentions of physical appearance}

It is a well-known fact that the media are unhealthily interested and biased regarding the physical aspect of women politicians, something that is disregarded in the case of men (things like age, height, weight, clothing, hairstyle, make-up, facial features, and others) but becomes central when discussing women candidates. However, there are reasons to believe, as recent studies indicate, that the effect of a candidate's appearance depends on the information environment in which voters are placed. As Danny Hayes, Jeniffer Lawless, and Gail Baitinger note, a number of studies suggest that a candidate's personal attributes, including visual appearance, should be most influential when those characteristics are emphasized by the media (Hayes, Lawless and Baitinger, 2014: 1196). Gabriel Lenz and Chappel Lawson (2011) state that candidate appearance has a major influence on citizens who are not well informed about politics but watch a lot of television (which may or may not be the case of the viewers of El Hormiguero). Second, a large literature in psychology demonstrates that, all else equal, negative information is more memorable and influential than positive information (Hayes, Lawless and Baitinger, 2014: 1196). The authors conclude that, even if negative coverage may affect equally male and female candidates, "gendered coverage throughout a campaign could activate voters' propensity to rely on gender stereotypes or exhibit gender bias" (Hayes, Lawless, and Baitinger, 2014: 1208). 
The data extracted from the analysis of this item (the mentions made by Motos and his guests about their physical appearance) reveal results every bit as surprising as those in the previous section. In general terms we observe that male candidates are subject to one or several questions regarding their outward appearance, whereas Sáenz de Santamaría's is not even mentioned once during her interview. Pedro Sánchez is the one whose physical characteristics receive the most attention. During his interview, a cut is made to footage of socialite Carmen Lomana, who addresses Sánchez with: "I personally love your good looks", and recommends him to dress more boldly. The puppets that occasionally intervene in the program, Trancas and Barrancas, express their opinion that "he must be well experienced in love with those dreamy little eyes", and also mention his height. In the case of Iglesias his most identifying feature (his long ponytail) becomes the subject of conversation, and they ask him if he will cut it if he becomes the next president. They also refer to those who use that feature to insult him, and Motos comments: "I have heard every single insult directed to you, A to Z: Ponytail this and Ponytail that), to which Iglesias replies: "Ponytail is no insult, I don't take it as such"). Eventually, the candidate promises: "If I win the election I will come back here and let my hair loose". In Rivera's interview he is introduced as a sportsman and mention is made of his past victories as a swimmer. In contrast with the alleged attractiveness of Sánchez, with Rivera's athletic physique, and with the long (and inappropriate for a president, as suggested in the show) hair sported by Iglesias, Sáenz de Santamaría's appearance is not mentioned even once. On the contrary, Motos decided to allude to other positive and flattering traits of character. For instance, he asked her whether she was ever tempted to shake President Rajoy out of his passivity: "You are a woman that is full of energy, Soraya; you are a woman of action".

How can this be interpreted? We must first remember that the emergence of a new generation of leaders in Spanish politics, younger, more modern, and generally thought of as more attractive, has prompted several comments in the media about how new that last trait is in the political scene, both in the case of men and of women. Secondly, and if (as mentioned earlier) only negative or derogatory comments exert a negative influence in the decision of the voters, we could wonder whether mostly positive assessments (at least in the case of Sánchez and Rivera) have any consequence at all. Be it as it may, it is clear that the attitude displayed by Pablo Motos represents a radical turn and an openly contrary position to the perpetuation of sexism that was the hallmark of other shows in previous campaigns.

\subsection{Sexist stereotypes}

The detailed analysis of the two previous categories might suggest that sexist questions and comments have completely disappeared from El Hormiguero and that TV writers have been made aware of the problems caused by sexist attitudes. However, sexism still underlies society's collective imagination and the media, something that becomes even more apparent when humor is invoked. Humor with sexist overtones, sometimes categorized as indirect 
sexism as opposed to blatant sexism, has been studied and the conclusions show that the effects of sexist humor increase men's tolerance of sexism in general. Prejudiced Norm Theory, as presented by Thomas Ford and Mark Ferguson (2004), contends that prejudiced (including sexist) jokes activate a change in the level of acceptance in a conversation or in an interview. As the authors state, a superficial atmosphere is created, resulting in a non-serious mindset on the part of the receiver, which prevents the message from being interpreted critically. By switching to such state of mind, the recipient of the joke essentially accepts the local norm implied by the joke. As such, when exposed to sexist jokes people may begin to accept the implied sexism, which may result in greater personal tolerance of discrimination.

Such is precisely the case in the interviews of El Hormiguero. Although sexism is absent from the production or the essential nature of the show, some examples betray an underlying current of sexism and stereotypical thinking. In the first place, mentions of the vice president's physical appearance, which were completely absent during her interview, arise repeatedly in the interviews of the male candidates. Her short height was mentioned several times in the shows in which Pedro Sánchez and Pablo Iglesias were interviewed. In the latest case, it was part of a parody sketch in which the main political figures were rounded up in a Whatsapp group. During the fictitious conversation, Sáenz de Santamaría was ridiculed for her short height; the mayor of Madrid, Manuela Carmena, for her advanced age, and Esperanza Aguirre for her alleged prudishness ("chaste and pure"). Despite the fact that the jokes also included Iñigo Errejón's childish looks, in the case of men punchlines tended toward their political performance (like associating Artur Mas with Catalonian independence and Jordi Pujol with political corruption).

Yet another moment of sexist humor comes up when Pablo Motos makes the following suggestion to Pedro Sánchez: "You should try to pick up Angela Merkel, see if you can soften up her heart. Picture yourself as the president. You take her out to dinner, you lend her a hand with her hairdresser $[\ldots]$ ". The suggestion evidences the perceived anomaly generated by Angela Merkel's strength, who, the joke seems to imply, would nevertheless be easily softened by the attentions of the young and handsome Socialist leader. We must point out Sánchez's reaction every time that he became involved in one of these jokes. In response to the suggestion made by Motos, he stated that he has worked closely with German politicians, both men and women, and that he has met several businesspeople in Germany. He thus stripped his answer of sexist overtones and drove the conversation back to the topic of politics and equality. Among the best contributions of the previous Socialist government, Sánchez lists those that are more closely linked to gender equality, and does not play along when it is mentioned that Sáenz de Santamaría probably did not play basketball (another taunting remark about her height). To this, Sánchez answered that height is not required to be a good player and, although he can be seen smiling and even laughing openly, in every occasion he made clear his opposition to such remarks, driving the conversation back to the 
topic of equality. For this reasons, his performance can be said to be frontally opposed to the model proposed by Ford and Ferguson (2004): the socialist candidate, being the recipient of the joke, rejects the sexist norm implied by the joke and moves the conversation towards a more egalitarian level. The puppets, at a different point in the show, claim to be more ferocious in their questioning than Ana Pastor (another host in the same channel, famous for her cutting style of journalism) when she is "in those days of the month", only to promptly add that they mean Sundays, when her show is broadcast. Humor, once again, is made using stereotypes linked to female biology, and undermines Pastor's professionalism by attributing her ability as an interviewer to her biological condition as a woman.

To finish this section we will make a brief mention of the entertainment tests to which candidates were subjected. Sáenz de Santamaría danced, which is not an activity that is specifically associated with either gender, as in the case of Pablo Iglesias, who sang a song. His choice of song, however, was Javier Krahe's ¿Dónde se habrá metido esta mujer? (Where the hell is this woman?), a story about a sexist husband abandoned by his wife. Iglesias also suggests that all women in similar situations should do the same. The tests of Albert Rivera (a car race) and Pedro Sánchez (a game of billiards) might have specifically male connotations, although these activities are in no way exclusive to men. The tests, more than communicating or perpetuating gender stereotypes, seek to catch the attention of the audience by engaging the candidates in unusual behaviors and activities, and openly contribute to the entertainment aspect of the show.

\section{Results and Final Considerations}

The predominance of male candidates and the existence of a glass ceiling in the political campaign can be corroborated by the fact that only one woman candidate was interviewed in the TV program under analysis (and just because she was standing in for the leader of her party), whereas three male candidates represented their political formations in the same show. However, regarding the traditional stereotyped treatment of candidates, El Hormiguero and its host, Pablo Motos, did not reproduce the commons sexist stereotypes in the least. As discussed in previous sections, Motos asked questions concerning personal and family life to the male candidates, and was more interested in speaking about profession and power with the female candidate. Nevertheless, and as already mentioned, sexist stereotypes still surfaced in the show in the guise of humor. Such persistence reveals a more complex pattern; even though the transcript of the interviews by Motos seem to suggest a major advancement in the achievement of an egalitarian treatment, the fact that sexist comments surface under the disguise of humor is a clear sign that discrimination is very present in the collective ideology 
of Spanish society. The indicators connected to the three areas analyzed that seemed to have been overcome (and even reversed) in the interviews return in other practices; the comments prompted by Sáenz de Santamaría similarly reveal an internalized belief in the need to present herself in the traditional role of wife and mother. Such elements contradict the results of the interview analyses.

The slow but continuous increase in the number of women in party lists and the progressive banishment of sexist stereotypes in television convey a certain sense of optimism and enable us to hope for a steady rise of women to positions of power. Studies carried out in the USA regarding the presence of women in prominent positions during electoral campaigns unanimously conclude that the greatest challenges for the advancement of women are the absence of women in political bases and their lack of interest or political ambition. The integration of more women to party lists in Spain will undoubtedly foster their rise to more relevant positions in their respective hierarchies. The success of women candidates in the previous local and regional elections, with women becoming mayors of the two main cities in Spain (Madrid and Barcelona) has been a turning point and a breach in the glass ceiling that heralds many others. Achievements at the local and regional level still seem far from affecting general elections, where the main candidates are still all men, but for the first time suggestions arise that women might replace the leaders of the two most-voted parties (PP and PSOE). Given the involvement of infotainment in the new political landscape, new studies will be required to analyze the presence of political figures and their interventions in entertainment shows (which include, among others, sports shows) as well as in "serious" news programs in which entertainment has already become an integral part of the content. From the point of view of gender issues, this might reveal new and relevant elements to be considered in the research of the new forms of political communication.

One final point worth mentioning is the power of the audiences in her observation and interpretation of such television programs. Although disguised as mere entertainment, the opportunity to become critical viewers by analyzing and contrasting the responses by the various candidates and to form an opinion on their possibilities as future leaders of the country is provided in these and other shows. In an effort to contemplate our power of intervention and our contributions to the abstract notion of power, Manuel Castells reminds us of our responsibility and capacity to modify the social and political landscape. Rather than despairing or complaining when we disagree with the social configuration, each individual has the chance to intervene: "However, the public mind is constructed by networking individual minds, such as yours. Thus, if you think differently, communication networks will operate differently, on the condition that not only you, but I and a multitude choose to build the networks of our lives" (Castells, 2009: 432). Such is both our task and our opportunity in the configuration of a more balanced representation of gender in national politics. 


\section{BIBLIOGRAFHY}

- Baudrillard, Jean (1994): Simulacra and Simulation. Ann Arbor: University of Michigan Press.

- Berrocal Gonzalo; Salomé; Redondo García, Marta; Martín Jiménez, Virginia and Campos Domínguez, Eva (2014): "La presencia del infoentretenimiento en los canales generalistas de la TDT española”. In: Revista Latina de Comunicación Social, nº. 69, pp. 85-103.

- Camille, Elizabeth and Roberson, Kasie M. (2010): "Playing the Gender Card against a Stacked Deck". In: Robert E. Denton (ed.): Studies of Identity in the 2008 Presidential Campaign. Lanham: Lexington Books, pp. 65-80.

- Castells, Manuel (2009): Communication Power. Oxford and New York: Oxford UP.

- Coleman, Stephen (2000): "Meaningful Political Debate in the Age of the Soundbite". In:

Televised Election Debates: International Perspectives. London: MacMillan, pp. 9-11.

- Debord, Guy (1995): The Society of the Spectacle. New York: Zone Books.

- Devitt, James (1999): Framing gender on the campaign trail: women's executive leadership and the Press. New York: Women's Leadership Fund.

- Dolan, Kathleen (2015): When Does Gender Matter? Women Candidates and Gender Stereotypes in American Elections. Oxford and New York, Oxford University Press.

- Fernández, Eduardo (2015): “Albert Rivera no puede con Pablo Iglesias en las 'elecciones' de 'El Hormiguero'. In: El Mundo, 25 de noviembre de 2015, [on line] Available at: http://www.elmundo.es/television/2015/11/25/56559acf22601de6068b45b0.html [24/12/2015].

- Ferré, Carmen (2013) (ed.): Infoentretenimiento. El formato imparable de la era del espectáculo. Barcelona: UOC.

- Ford, Thomas and Ferguson, Mark (2004): "Social Consequences of Disparagement Humor: A Prejudiced Norm Theory”. In: Personality and Social Psychology Review, vol. 8, n.1, pp.7994.

- Groch-Begley, Hannah (2016): “A Comprehensive Guide to Sexist Attacks On Hillary Clinton From The 2008 Campaign”. In: Media Matters for America, [on line] Available at: http://mediamatters.org/research/2016/02/05/a-comprehensive-guide-to-sexist-attacks-onhill/199700 [09/01/2016].

- Hayes, Danny; Lawless, Jennifer and Baitinger, Gail (2014):"Who Cares What They Wear? Media, Gender, and the Influence of Candidate Appearance”. In: Social Science Quarterly, $\mathrm{n}^{\circ}$. 95, pp. 1194-1212.

- Lawless, Jennifer L. and Fox, Richard L. (2012): It Still Takes a Candidate. Why Women Don't Run for Office. New York: Cambridge University Press.

- Lenz, Gabriel S. and Chappell, Lawson (2011): "Looking the Part: Television Leads Less Informed Citizens to Vote Based on Candidates' Appearance”. In: American Journal of Political Science, vol. 55, no. 3, pp. 574-89.

- Lipovetsky, Gilles (2005): Hypermodern Times. Cambridge: Polity Press. 
- Lockwood, Nancy (2004): "The Glass Ceiling: Domestic and International Perspectives". In: Research Quarterly, pp. 1-11.

- McNair, Brian (1998): The Sociology of Journalism. New York: Oxford UP.

- O’Leary, Pamela and Shames, Shauna (2015): "Shattering the Glass Ceiling for Women in Politics". In: Scholars Strategy Network, [on line] Available at:

https://www.scholarsstrategynetwork.org/sites/default/files/ssn_basic_facts_oleary_and_shames _on_shattering_the_glass_ceiling_for_women_in_politics_0.pdf [29/12/2015].

- Rodríguez, María Pilar (2012) (ed.): Representaciones de las mujeres políticas en la prensa. Bilbao: Publicaciones de la Universidad de Deusto.

- Simelio, Nuria (2015) (coord.): "Proyecto de Monitoreo Global de Medios 2015. Informe Nacional". In: Who makes the news, [on line] Avaliable at: http://cdn.agilitycms.com/whomakes-the-news/Imported/reports_2015/national/Spain.pdf [19/12/2015].

- Thussu, Daya Kishan (2007): News as Entertainment: The Rise of Global Infotainment. Los Angeles, London, New Delhi and Singapore: Sage.

- Van Dijk, Teun A (1999): “El análisis crítico del discurso". In: Anthropos, no. 186, pp. 2336. 